\section{An Interview with Austrian Composer Werner Schulze}

\author{
ANTON A. ROVNER \\ Moscow State P.I. Tchaikovsky \\ Conservatory, \\ Moscow, Russia, \\ antonrovner@mail.ru, \\ https://orcid.org/0000-0002-5954-3996
}

\section{Интервью с австрийским композитором Вернером Шульцем}

\section{АНТОН АРКАДЬЕВИЧ РОВНЕР}

\author{
Московская государственная консерватория \\ им. П.И. Чайковского, \\ 2. Москва, Россия, \\ antonrovner@mail.ru, \\ https://orcid.org/0000-0002-5954-3996
}

\begin{abstract}
The following interview with Austrian composer Werner Schultze presents the composer's biography and artistic evolution. The composer describes his musical style, his interest in other disciplines, and his efforts to conjoin different branches of knowledge together with music and to give each one of them a musical interpretation. Thereby, his efforts result in such striking phenomena as "Philosophy in Music, "Theology in Music," "Mathematics in Music," each of these categories becomes realized by original highly-imaginative musical compositions, such as "Lull" (devoted to the medieval mystic Ramon Lull), "Schopfunggesange" ("Songs to the Creation of the World"), "Franziscus" (honoring St. Francis of Assissi), "Anchibasie” (devoted to the Greek philosopher Heraclitus), "Sokrates" (written about the life and death of Socrates, according to Plato's texts) and many others.
\end{abstract}

\section{Keywords:}

Werner Schultze, composer, Austria, contemporary music, Philosophy in Music, Theology in Music, Mathematics in Music, chamber music, orchestral music, music for chorus and orchestra, music for solo singers and orchestra

\begin{abstract}
Аннотация. Предлагаемое интервью с современным австрийским композитором Вернером Шульце представляет биографию и творческое становление композитора. Шульце описывает свой музыкальный стиль, интерес к другим дисциплинам, свои попытки связать воедино различные области знания и каждую из них наделить музыкальной интерпретацией. Его усилиями появились такие яркие явления, как «философия в музыке», «теология в музыке», «математика в музыке», и каждая из этих категорий реализуется весьма изобретательными музыкальными произведениями, такими как «Лулл» (посвящено средневековому мистику Рамону Луллу), Schopfunggesange («Песни о сотворении мира»), Franziscus (посвящено св. Франциску Ассисскому), «Анхибасия» (посвящено греческому философу Гераклиту), Sokrates (о жизни и смерти Сократа по текстам Платона) и многими другими.
\end{abstract}

\section{Ключевые слова:}

Вернер Шульце, композитор, Австрия, современная музыка, философия в музыке, теология в музыке, математика в музыке, камерная музыка, оркестровая музыка, музыка для хора и оркестра, музыка для солистов с оркестром 
For citation:

Rovner A.A. An Interview with Austrian Composer Werner Schulze. ICONI. 2021. No. 4, pp. 135-141. https://doi.org/10.33779/2658-4824.2021.4.135-141.

Для цитирования:

Ровнер А.А. Интервью с австрийским композитором Вернером Шульцем // ИКОНИ / ICONI. 2021. № 4. С. 135-141. (На англ. яз.) https://doi.org/10.33779/2658-4824.2021.4.135-141.

A nton Rovner: Mr. Schulze, can you tell us, where were you born, where did you study composition, and what were your first musical influences?

Werner Schulze: I was born in 1952 in the Austrian town called Wiener Neustadt, located 50 kilometers south of Vienna. I live there now, as well. Only during the 40 years being a professor at the University of Music and the Performing Arts I lived in Vienna. But never in my life have I lost connection with my initial home, a small and beautiful town of 45 thousand people. As a boy I attended not only the Humanistic Gymnasium, but also the Music School. I studied the piano, as well as the recorder (Blockflöte in German), which is a popular instrument in Austria, especially for pedagogic use. At the age of 14 and 15 my main interest was focused on Berlioz' and Richard Strauss' treatises on instrumentation, which I venerated as the Bible. At that time, I actively developed my interest in the instruments of the symphony orchestra. Then I started learning to play the bassoon, which at that time was very difficult for me, and virtually impossible to study in the small town where I lived. So at the age of 16, though continuing to live in Wiener Neustadt and attending school for two more years, once a week I travelled to Vienna to study bassoon at the Academy of Music (now the University of Music and Performing Arts in Vienna). After I finished my studies in school, I moved to Vienna in order to study at two universities simultaneously. I studied philosophy at the University of Vienna, supplementing it with a little mathematics and theology. However, my main interest has always been ancient languages - in school I enthusiastically studied Greek and Latin, while at the University of Vienna I studied Ancient Babylonian, so I was even able to translate some parts of the Codex of Hammurabi in the original. At the same time, I pursued my musical studies at the Academy of Music, continuing my bassoon lessons. I also studied a special field - which I later taught as a professor - called "Harmonic Research" (Harmonikale Forschung) or "Harmonic Fundamental Research". Since the year 2000 we have started using the American English word "Harmonics." As you know, "harmonics" means the overtone series, but this is merely the physical, acoustic meaning of the word. However, the Ancient Greek term "harmonics" as used by Ptolemy, means: to find relationships and analogies between the harmony of the spheres, the mathematics of music and the mathematical fundaments of architecture, a type of thinking which starts with Plato's philosophy. So this is what I taught as a professor at the University of Music and the Performing Arts in Vienna, and I established a department for researching and teaching this subject, called the International Centre of Harmonics (Internationales Harmonik Zentrum). Seven years ago, in 2014 I retired from teaching at the university.

Anton Rovner: You have mentioned your interest in philosophy. What philosophy are you most interested in? Is your music related in any way to your philosophical interests?

Werner Schulze: I am especially interested in the Pythagorean and Platonic philosophy, but also in Christian theological philosophy. Obviously, I compose music 
in that vein, expressing the state when philosophy and theology meet.

Anton Rovner: Which of your compositions are most connected with Pythagorean and Platonic philosophy?

Werner Schulze: An entire group of my musical compositions are called "Philosophy on Stage," and another group I label as "Theology on Stage." There are altogether not more than seven such compositions, because I have completed these cycles.

Anchibasie, composed in 2004, is a dance-music-language work containing texts in Ancient Greek by the early Greek philosophers Heraclitus and Empedocles. Its title can be translated from Ancient Greek as “approximation”. Only 126 small fragments of Heraclitus' texts have survived up to the present day, and the shortest of these fragments consists of only one word - "anchibasíe". I took these old, historical texts and combined them with music and dance. The composition is written for two dancers, two singers and chorus, the part of which includes dance motion, and six instrumentalists - the latter parts can be performed on different alternating instruments at liberty. This composition combines philosophy, poetry, music, and stage action. It has been performed five times altogether.

Sokrates is a theatrical drama with music, which I define as a "Stationen-MusikTheater," written in 2002/03 entirely to my own dramatic text, derived in part from Plato's writing, about the life and death of Socrates.

I have also composed Passio, a Passion different from Johann Sebastian Bach's monumental works: My composition is written on a text in Ancient Greek, the part of Jesus is sung by a soprano, and the entire work is quite theatrical in its approach. The libretto combines texts from all four Gospels (the greatest amount of text taken from the Gospel according to St. John, and the minimal amount of text coming from St. Luke) and my own text. In my composition I depart from the traditional approach of
Passions by also including the narration of the Resurrection of Christ, something which usually is not done in this genre. I decided to make this inclusion, so that the composition could also be performed on Easter Sunday.

Anton Rovner: As I understand, many of these compositions are essentially oratorios in their genre. Many of them are composed for soloists, chorus and orchestra and are settings of religious texts.

Werner Schulze: Yes, most of these compositions can be compared to oratorios in their genre. My composition $L L U L L$ written in 1998/99 in honor of the great medieval Catalan religious thinker Ramon Llull I call a "Logo-Mysterion," since it pertains to both philosophy and theology. It could be described as an oratorio, since it is written for orchestra (flute, oboe, soprano saxophone, two trombones, percussion, piano, organ, strings), soprano solo, mixed chorus and a speaker set to a text in old Catalan (or, better to say, Majorcan). Since Ramon Llull was a religious mystic, he wrote many logo-mystical books which I set to music and which I classify not as "theology", but as "theo-logic", since in it theology and logic come together. The text for the speaker can be performed in any other language, depending on what country my work is performed. For example, in the year 2000 it was performed on the Faroe Islands in the North Atlantic during the celebration of the thousandth anniversary of the arrival of Christianity on the Faroe Islands. So this composition was performed there for the occasion in Faroese, along with Brahms' "Ein Deutsches Requiem". Faroese is a language, resembling a blend of Icelandic and Norwegian, and it is spoken on these islands, which have a population of only 51 thousand people.

My composition Schöpfungsgesänge (Cantos de Creación, Chants of Creation) describes the creation and essential aspects of the world, although differently from the canonic Biblical approach. It was set to small fragments from the book "Cántico Cósmico" of Ernesto Cardinal, a famous 
Nicaraguan priest who was at odds with the establishment of the Catholic Church, and was eventually excluded from it. His book deals with natural sciences and philosophy, combined with myths and fairytales, on the one hand, and Christian thinking, on the other hand.

Cantico di Frate Sole, devoted to St. Francis of Assisi, is written for an ensemble of soprano, two string quartets, contrabass and piano. It explores the original medieval text of St. Francis of Assisi written in early Italian.

Anton Rovner: So, as I understand, "Philosophy on Stage" and "Theology on Stage" are for the most part compositions for soloists, chorus and instrumental ensembles? Are there any exceptions to this? Do these categories include any works written in other genres?

Werner Schulze: The only exception is my quartet Logos. It can be compared to Olivier Messiaen's quartet for clarinet, violin, violoncello and piano, but consists of clarinet, bassoon, violoncello and piano. The musical score does not include any text, but it includes a part for light, involving projections of different colors, which change during the three movements of the work, each one, respectively, describing God the Father, the Son and the Holy Spirit.

Anton Rovner: And you also have a category called "Mathematics on Stage"?

Werner Schulze: Yes, this section consists of only one work, an opera essentially about mathematics. Kalkül is a theatre opera set to the text of Carl Djerassi, composed in 2004, it was performed first 2005 at the Zürich Opera House on the occasion of the 150th anniversary of the "EidgenössischTechnische Hochschule." Its plotline describes a famous fight in the history of mathematics which took place between the famous philosopher-mathematicians Gottfried Wilhelm Leibnitz and Isaac Newton, the latter was the first to have invented the "calculus differentialis". Kalkül was about this argument between these two minds regarding their mathematical invention, which took place during the course of about 35 years. The opera is scored for soprano, alto, tenor and bass voices, theatrical players and a chamber ensemble of flute, oboe, clarinet with contrabass clarinet, bassoon, trumpet, trombone, two violins, viola, violoncello, contrabass and piano/harpsichord. This opera includes one section, in which all the musicians must also demonstrate themselves as theatrical actors.

Anton Rovner: Can you tell us about your work "Oedipus"? Is it based on Sophocles' tragedy? What is it composed for?

Werner Schulze: My operatic work "Oedipus" was composed for narrator, puppeteer, actors, chorus, and Javanese gamelan orchestra, and it lasts for two hours. I turned to the gamelan orchestra, because Indonesia is essentially my second home. So it was a completely new experience for me. I developed a new kind of musical score created especially for gamelan orchestra, which involves notation involving only Arabic numbers.

Anton Rovner: This is all very intriguing. You have demonstrated yourself as being a very bright and versatile composer. Besides your operas and works on stage, have you also composed any purely instrumental pieces?

Werner Schulze: Yes, I have composed solo pieces for almost all the orchestral instruments, even for some rare ones, like the heckelphone, a kind of a baritone or bass oboe.

Anton Rovner: This is quite unusual. The only place I have encountered the name of the heckelphone was in Walter Piston's book "Orchestration". I have never seen them or heard about them anywhere else. I thought they are completely obsolete by now.

Werner Schulze: No, they do exist, and some composers write for them. I can tell you about them, because I am a specialist in the world of the heckelphone. There are currently only 165 instruments altogether throughout the world, made from 1904 to 2012. Presently two more instruments are now being built, and they will be finished in 
two or three years. I was the owner of one of these instruments.

Anton Rovner: In what countries are these instruments present? I have never heard of heckelphones being available at all in Russia, nor in the United States. Perhaps, they can be found in some of the European countries?

Werner Schulze: If you are interested about the instrument, you can visit the website http://www.heckelphone.org, and you will see, among other things, a list of which countries have this instrument. And if you go to \#3197 on this website, you will find some information about me. There are many heckelphones in Germany, about 45\% of them, four instruments in Austria, and about $40 \%$ of them are in the United States.

Anton Rovner: Can you tell us about some of your other compositions for chamber ensemble?

Werner Schulze: I have an assortment of chamber compositions, many of them bearing colorful titles and peculiar conceptions. Let us start with some works for solo instruments. Fibonacci Haiku for bassoon solo is one example of this group. As the title indicates, it makes use of the Fibonacci series as its main structural element. As I have played the contrabassoon many times, I know how to write for this instrument and to evoke its most expressive and virtuosic aspects; the title of my solo composition is Contrafagottophonia. Holzwege [Wooden Paths] is written for a special kind of organ - an Italian organ named "Organo di legno" containing 14 notes per octave (instead of the usual 12). And, of course, I have written some compositions for piano solo: Farben und Zeiten is not evoked by any literary work or plotline, but inspired by particular images and psychic attributes. Poesie des Augenblicks for piano solo is also not based on any literary text or story. Another example is a short piece called Aus Stein gehauen [Carved out from Stone].

Anton Rovner: Have you composed many works for chamber ensembles?

Werner Schulze: I have written many duos, trios and quartets for various ensembles of instruments. Sketches \& Catches for baritone, bassoon and piano is based on my own poems. Concerto $R<$ oberto $>N$ in my opinion is an especially important work. In 2022 there will be film especially made especially for this music - it will be a case of not music made to a film, but a film made to music. It consists almost entirely of harmonics, while my friend's name is Roberto, and he is from Oslo, Norway. So I combined together the words "Roberto" and "Oberton," the German word of "overtones", to create the title of this work. It is the most incredible bassoon concerto ever, composed for bassoon and three other instruments, altogether combining to four instruments.

Anton Rovner: What is the overall style of your music? Do you adhere to an atonal, avant-garde style, or to a tonal, traditional style?

Werner Schulze: I have compositions written in a more avant-garde idiom, as well as works with tonal harmonies composed in a more traditional style. My chamber opera Trygaios is a serious comedy set to the famous play by Aristophanes, so I thought that any experimental style and textures would be inappropriate. The work is meant to be performed for an understanding and appreciative audience, preferably also endowed with a sense of humor. The stylistic directedness also depends on the period of my life. When I was younger, I was more interested in experimental stylistic trends. Now that I have grown older, I have become more interested in a simpler, more accessible style, which, although not being entirely diatonic, are certainly endowed with a tonal centricity. I am not really interested in twelve-tone music, but prefer much more "eleven-tone music." in the latter case, only one pitch is missing in the harmony, but when this pitch after ten or twelve minutes finally appears, it brings in a charge of energy.

Anton Rovner: Couldyou tell us something about your opera "Trygaios" for baritone and chamber ensemble?

Werner Schulze: Trygaios was composed with my own libretto based on Aristophanes' 
play. Recently it has been performed in July 2021 at the contemporary music festival "Two Days and Two Nights of New Music" in Odessa, Ukraine by Austrian baritone Rupert Bergmann and the Senza Sforzando chamber ensemble directed and conducted by Oleksandr Perepelitsya Jr. I have previously told a little about my drama with music "Sokrates". Rupert Bergmann has been one of the actors for the several performances of this work, which took place in 2003 in an empty Gothic church in my hometown. After a few repeated performances of this work, Rupert and the pianist who accompanied him asked me to compose songs for him. At first I refused the offer, but after two or three weeks of thinking about it, I finally accepted it. I composed the previously mentioned "Sketches and Catches", settings of my own texts, which are short, and most of which are quite funny. The songs were for bass-baritone, bassoon and piano. Rupert performed them six times already in Austria. After that he told me about the festival "Two Days and Two Nights of New Music" in Odessa in which he had participated several times and suggested me to compose a so-called mini-mono-opera, which he could perform in Odessa, as well as in Austria. I asked him, what subject I should take for the opera. Previously, I had composed a considerable amount of serious music about austere subject matter, such as "Oedipus" or "Passio", but I had never composed any musical settings of Greek comedies. This side of art was empty in my life. I had a special fondness for Aristophanes' play "Eiréne", so I decided to compose my opera to that play. Rupert told me that the opera should be no more than 25 minutes long, so I had to compose a work 24 minutes long! The work is written for baritone, clarinet, violin, violoncello, piano and percussion, almost entirely in a tonal harmonic idiom, with textures close to neoclassical ones, and it has a very merry, humorous mood. Rupert Bergmann gave it an excellent performance, singing in a virtuosic manner, as well as running around and jumping on stage in a very jovial theatrical way.
Anton Rovner: Can you tell us about your compositions which you call "Grotesken"?

Werner Schulze: Der Untergang des römischen Imperiums is a peculiar kind of opera about Gaius Julius Caesar, who was murdered by Brutus and his group of conspirators, as we all know. The plotline of this opera contains grotesque "facts" about his death. In the Roman Capitol there were two Austrian civil servants, who were actually responsible for the death of Caesar. The plot involves a lady, Perma Penetrantia, as well as many other interesting details. Later I took fragments from this work, in the manner of Stravinsky, and composed an instrumental work for orchestra in 10 movements, which I called Civil Servants Symphony. Although, being essentially a symphony, it carries this title, since much of the music from it was derived from the opera.

Anton Rovner: You have demonstrated yourself as a brilliant, versatile and prolific composer. What other forms of musical activities do you engage yourself, besides composing?

Werner Schulze: I also actively study the music of the great masters and teach it in my classes. I have also worked in philosophical and musical publications. For one publishing project I have edited the Fugue by Johann Sebastian Bach from his Sonata for solo violin BWV 1003. I have found in this work the clear architectural design, which contains seven sections. If you look at my analysis, you can see that exactly in the middle of the work, after 144 measures, there is the basic accord with a mirror reflection of the music in its structure, and the fifth section of this work is directly connected with the third section, while the very short second section is directly connected with the very short sixth section. The organism of this fugue has a direct connection with theology, since it contains the prayer Pater Noster [Our Father]. So the seven sections of the Lord's Prayer are directly mirrored in the seven sections of this fugue. These are some examples of the kind of analysis of classical music I carried out. 
Anton Rovner: What are your plans for the upcoming future?

Werner Schulze: As I call myself a cosmopolitan (Weltbürger) I'm happy looking forward to performances in Romania, Faroe Islands, Indonesia and Ukraine. My compositional projects are Lungauer Nachtmusik (Night Music) and a new work for Odessa in 2023. But before I have my 70th birthday with a special minimarathon concert ...

Information about the author:

Anton A. Rovner, Ph.D. (Arts), faculty member at the Department of Interdisciplinary Specializations for Musicologists, Moscow State P.I. Tchaikovsky Conservatory; Associate Professor at the Department for Philosophy, Sociology and Culturology, Moscow University for the Humanities (Moscow, Russia).

Информация об авторе:

Ровнер Антон Аркадьевич, Ph.D., преподаватель кафедры междисциплинарной специализации по музыковедению, Московская государственная консерватория им. П.И. Чайковского (Moscow, Russia).

The article was submitted 09/01/2021; approved after reviewing 09/20/2021; accepted for publication 11/01/2021.

Статья поступила в редакцию 01.09.2021; одобрена после рецензирования 20.09.2021; принята к публикации 01.11.2021. 